\title{
The Changes in Triglyceride and Total Cholesterol Concentrations in the Liver and Muscle of Two Fish Species from Qarun Lake, Egypt
}

\author{
Amal S Mohamed ${ }^{1 *}$, Mohamed A El Desoky² and Nahed S Gad ${ }^{1}$ \\ ${ }^{1}$ National institute of oceanography and fisheries, Egypt \\ ${ }^{2}$ Faculty of Science, Cairo University, Egypt
}

Submission: March 11, 2019; Published: March 29, 2019

Corresponding author: Amal S Mohamed, National institute of oceanography and fisheries, Egypt

Abstract

The level of Triglycerides and total cholesterol were determined in the liver and muscle of fish T. zillii and M. capito seasonally during (August 2014 to May 2015) from east, middle, and west of Lake Qarun. The results revealed that the concentrations of triglycerides were significant increased $(\mathrm{p} \leq 0.05)$ in two fish species comparison with the control fish samples collected from unpolluted site (fish farm). Also, the present study revealed that total cholesterol in the liver and muscle of T. zilli was increased significantly $(\mathrm{p} \leq 0.05)$ in comparison with the control fish samples collected from unpolluted site (fish farm) with percentage ranged between 9.20-73.87\% except in the liver sample collected from western part in summer that was not significant increased with percentage $2.66 \%$. While total cholesterol in the liver and muscle of $M$. capito was increased significantly ( $\mathrm{p} \leq 0.05$ ) in comparison with the control with percentage ranged between $31.03-184.2 \%$.

Keywords: Triglycerides, Total cholesterol, M.capito, Qarun lake

\section{Introduction}

Biochemical studies can be an available tool for identifying ecosystems contaminated by various pollutants or for following changes in such system through times [1]. Analysis of biochemical parameters could help to identify the target organs of toxicity as well as the general health status of animals. It may also provide an early warning signal in stressed organism [2]. Fish have been proposed as indicators for monitoring land-based pollution because they may concentrate indicative pollutants in their tissue, directly from water through respiration and through their diet. Fish are frequently subjected to prooxidant effects of different pollutants often present in the aquatic environment [3]. Triglycerides are water-insoluble lipids consisting of three fatty acids esterified to a glycerol backbone. Triglycerides are transported in the blood as core constituents of all lipoproteins but are major components of triglyceride-rich chylomicrons and very low-density lipoproteins (VLDL) [4].

The measurement of triglyceride levels, in conjunction with other lipid assays, are useful in the diagnosis of primary and secondary hyperlipoproteinemia, dyslipidemia, and triglyceridemia. Triglyceride concentrations are also useful in the diagnosis and treatment of diabetes mellitus, nephrosis, liver obstruction, and other diseases involving lipid metabolism or various endocrine disorders [5]. Cholesterol is the major sterol in animal tissue. Cho lesterol and its esters with long chain fatty acids are important components of plasma lipoprotein and of the outer cell membrane. It stimulates utilization of fatty acids and ketogenesis. Cholesterol is also important for the synthesis of bile acids, which facilitate the emulsification, and digestion of lipids in the small intestines [6]. Cholesterol belongs to one of a group of steroids compounds which have in common the basic phenanthrene derivative, although it is a precursor for sex steroid hormones in the gonads and is obtained normally from circulating low-density lipoprotein, it can be synthesis (denova) in the gonads from two carbon fragment Acetyl Co A [7].

Cholesterol is a critical compound used in the structure of cell membranes, hormones, and cell signaling. It is an essential component of animal cell structure in order to maintain permeability and fluidity. Cholesterol exists within a lipoprotein as a free alcohol and as a fatty cholesteryl ester, which is the predominant form of cholesterol transport and storage. Total lipid was formed by the cholesterol, phospholipid, and triglyceride and so the elevation in its components leads to the increase in total lipid [8]. The level of total lipids, triglycerides and total cholesterol in tissues of fish have been reported to be moderately sensitive to environmental pollutant but the direction of change in these parameters seems to be dependent on many factors, such as the types of contami- 
nant, the concentration, mode of its action, duration of exposure and fish species [9]. Changes in these parameters generally reflect the state of the animal nutrition, endocrine function as well as integrity of the vital organs especially the liver and kidneys [10].

\section{Materials and Methods}

\section{Study Area}

Qarun Lake is a closed elongated saline basin located between longitudes $30^{\circ} 24^{\prime} \& 30^{\circ} 49^{\prime} \mathrm{E}$ and latitudes of $29^{\circ} 24^{\prime} \& 29^{\circ} 33^{\prime} \mathrm{N}$ in the lowest part of El-Fayoum depression, about $80 \mathrm{~km}$ Southwest of Cairo. It has an irregular shape of about $40 \mathrm{~km}$ length and about $6 \mathrm{~km}$ mean width, with an average area of about $240 \mathrm{~km}$. The lake is shallow, with a mean depth of $4.2 \mathrm{~m}$ and about $20 \%$ of the lake's area has a depth ranging between 5 to 8 meters. The water level of the lake fluctuated between 43 to $45 \mathrm{~m}$ below mean sea level [11].

\section{Sampling}

Samples of fish T. ziliii and M. capito were collected from the east, middle and west of Lake Qarun. The fish measured about (12 to 15 ) and (20 to $24 \mathrm{~cm}$ ) in total length and (40 to 67 ) and (81

Results

\section{Triglyceride Concentration}

Table 1: Tri glyceride concentrations (mg/dl) (Means $\pm \mathrm{SE}$ ) in the liver of T.zilli collected from lake Qarun.

\begin{tabular}{|c|c|c|c|c|c|c|c|}
\hline location/season & control & East & \%Alteration & middle & \%Alteration & west & \%Alteration \\
\hline Summer & $72 \pm 1.18$ & $213.3 \pm 1.10^{*}$ & 196.2 & $181.3 \pm 1.84^{*}$ & 151.8 & $162.7 \pm 2.01^{*}$ & 125.9 \\
\hline Autumn & $114.7 \pm 1.38$ & $237.3 \pm 1.84^{*}$ & 106.8 & $210.7 \pm 1.38^{*}$ & 83.6 & $216 \pm 1.07^{*}$ & 88.3 \\
\hline Winter & $72 \pm 1.39$ & $149.3 \pm 2.33^{*}$ & 107.3 & $120 \pm 1.39 *$ & 66.6 & $114.7 \pm 0.70^{*}$ & 59.3 \\
\hline Spring & $114.7 \pm 0.93$ & $157.3 \pm 1.62^{*}$ & 37.1 & $172 \pm 1.86^{*}$ & 49.9 & $172 \pm 2.11^{*}$ & 49.9 \\
\hline
\end{tabular}

-Data are presented as mean \pm SE of 6 fish. - SE: standard error. \%Alteration from control value * significant difference from control at ( $p \leq 0.05)$.

Table 2: Tri glyceride concentrations (mg/dl) (Means $\pm \mathrm{SE})$ in the muscle of $T$. zilli collected from lake Qarun.

\begin{tabular}{|c|c|c|c|c|c|c|c|}
\hline location/season & control & East & \%Alteration & middle & \%Alteration & west & \%Alteration \\
\hline Summer & $138.7 \pm 1.38$ & $330.7 \pm 0.75^{*}$ & 138.4 & $322.7 \pm 0.69 *$ & 132.6 & $269.3 \pm 2.33^{*}$ & 94.1 \\
\hline Autumn & $165.3 \pm 1.38$ & $482.7 \pm 0.69 *$ & 192 & $402.7 \pm 0.69 *$ & 143.6 & $325.3 \pm 0.767^{*}$ & 96.6 \\
\hline Winter & $120 \pm 1.11$ & $162.7 \pm 0.70 *$ & 35.5 & $160 \pm 0.82 *$ & 33.3 & $360 \pm 1.89 *$ & 200 \\
\hline Spring & $138.7 \pm 1.61$ & $213.3 \pm 1.62 *$ & 53.7 & $216 \pm 1.49 *$ & 55.7 & $266.7 \pm 1.42^{*}$ & 92.2 \\
\hline
\end{tabular}

-Data are presented as mean \pm SE of 6 fish. - SE: standard error. \%Alteration from control value *significant difference from control at (P $\leq 0.05)$.

In T. zilli Fish: The changes in triglyceride Concentrations in the liver and muscle of T. zilli fish collected from east, middle, west of Lake Qarun were represented in (Tables 1-2). The results revealed that the concentrations of triglycerides were significant increased $(p \leq 0.05)$ in comparison with the control fish samples collected from unpolluted site (fish farm) with percentage ran-

ged between 33.3-200 \%. The lowest values in liver and muscle of $T$. zillii were ( $114.7 \pm 0.70$ and $160 \pm 0.82 \mathrm{mg} / \mathrm{dl}$ respectively) recorded in winter in the western part of the lake and in autumn in the middle part respectively. While, the highest values were $(237.3 \pm 1.84$ and $482.7 \pm 0.69 \mathrm{mg} / \mathrm{dl})$ respectively in autumn season in the eastern part.

Table 3: Tri glyceride concentrations ( $\mathrm{mg} / \mathrm{dl})($ Means $\pm \mathrm{SE})$ in the liver of $M$. capito collected from lake Qarun.

\begin{tabular}{|c|c|c|c|c|c|c|c|}
\hline location/season & control & East & \%Alteration & middle & \%Alteration & west & \%Alteration \\
\hline Summer & $106.7 \pm 1.44$ & $244 \pm 0.91^{*}$ & 128.6 & $218.7 \pm 0.80^{*}$ & 104.9 & $224 \pm 0.82^{*}$ & 109.9 \\
\hline Autumn & $109.3 \pm 0.70$ & $141.3 \pm 1.84^{*}$ & 29.2 & $144 \pm 1.18^{*}$ & 31.7 & $162.7 \pm 0.69^{*}$ & 48.8 \\
\hline Winter & $96 \pm 1.49$ & $160 \pm 1.39^{*}$ & 66.6 & $186.7 \pm 1.16^{*}$ & 94.4 & $152 \pm 1.18^{*}$ & 58.3 \\
\hline Spring & $109.3 \pm 0.91$ & $166.7 \pm 1.95^{*}$ & 52.5 & $157.3 \pm 1.62^{*}$ & 43.9 & $181.3 \pm 0.75^{*}$ & +65.8 \\
\hline
\end{tabular}

-Data are presented as mean \pm SE of 6 fish. - SE: standard error. \%Alteration from control value *significant difference from control at (P $\leq 0.05)$. 
In M. capito Fish: The changes in Triglyceride Concentrations in the liver and muscle of $M$. capito fish were represented in (Tables 3-4). The results revealed that the concentrations of triglycerides were significant increased $(p \leq 0.05)$ in comparison with the control fish samples collected from unpolluted site (fish farm) with percentage ranged between $29.2-231.3 \%$. The lowest values in liver and muscle of $M$. capito were $(141.3 \pm 1.84$ and $170.7 \pm 1.16$ Table 4: Triglycerides concentrations ( $\mathrm{mg} / \mathrm{dl}$ ) (Means $\pm \mathrm{SE}$ ) in the muscle of $M$. capito collected from lake Qarun

\begin{tabular}{|c|c|c|c|c|c|c|c|}
\hline location/season & control & East & \%Alteration & middle & \%Alteration & west & \%Alteration \\
\hline Summer & $118.3 \pm 1.27$ & $159.7 \pm 0.88^{*}$ & 34.9 & $258.7 \pm 0.80^{*}$ & 118.6 & $322.7 \pm 0.76^{*}$ & 172.7 \\
\hline Autumn & $117 \pm 0.81$ & $272 \pm 1.86^{*}$ & 132.4 & $322.7 \pm 0.69 *$ & 175.8 & $234.7 \pm 0.69 *$ & 100.5 \\
\hline Winter & $118.3 \pm 1.27$ & $392 \pm 1.39 *$ & 231.3 & $170.7 \pm 1.16^{*}$ & 44.2 & $178.7 \pm 2.33^{*}$ & 51.05 \\
\hline Spring & $120 \pm 0.72$ & $237.3 \pm 0.70 *$ & 97.7 & $228 \pm 1.86^{*}$ & 90 & $248 \pm 2.43^{*}$ & 106.6 \\
\hline
\end{tabular}

-Data are presented as mean \pm SE of 6 fish. - SE: standard error. \%Alteration from control value * significant difference from control at $(P \leq 0.05)$.

\section{Total Cholesterol Concentrations}

Table 5: Total cholesterol concentrations (mg/dl) (Means $\pm \mathrm{SE}$ ) in the liver of $T$. zillii collected from lake Qarun.

\begin{tabular}{|c|c|c|c|c|c|c|c|}
\hline location/season & control & East & \%Alteration & middle & \%Alteration & west & \%Alteration \\
\hline Summer & $4.13 \pm 0.086$ & $4.55 \pm 0.068^{*}$ & 10.16 & $6.17 \pm 0.090^{*}$ & 49.39 & $4.24 \pm 0.053$ & 2.66 \\
\hline Autumn & $2.77 \pm 0.072$ & $3.28 \pm 0.068^{*}$ & 18.41 & $3.32 \pm 0.044^{*}$ & 19.85 & $3.32 \pm 0.060^{*}$ & 19.85 \\
\hline Winter & $3.01 \pm 0.038$ & $4.55 \pm 0.086^{*}$ & 51.16 & $4.40 \pm 0.066^{*}$ & 46.17 & $4.51 \pm 0.058^{*}$ & 49.83 \\
\hline Spring & $4.13 \pm 0.073$ & $4.51 \pm 0.084^{*}$ & 9.2 & $4.51 \pm 0.071^{*}$ & 9.2 & $4.98 \pm 0.124^{*}$ & 20.58 \\
\hline
\end{tabular}

-Data are presented as mean \pm SE of 6 fish. - SE: standard error. \%Alteration from control value * significant difference from control at ( $\mathrm{p} \leq 0.05)$.

Table 6: Total cholesterol concentrations (mg/dl) (Means $\pm \mathrm{SE}$ ) in the muscle of $T$. zillii collected from Lake Qarun.

\begin{tabular}{|c|c|c|c|c|c|c|c|}
\hline location/season & control & East & \%Alteration & middle & \%Alteration & west & \%Alteration \\
\hline Summer & $5.25 \pm 0.058$ & $5.98 \pm 0.047^{*}$ & 13.9 & $7.72 \pm 0.060^{*}$ & 47.05 & $8.64 \pm 0.056^{*}$ & 64.57 \\
\hline Autumn & $4.01 \pm 0.072$ & $5.75 \pm 0.060^{*}$ & 43.39 & $4.44 \pm 0.073^{*}$ & 10.72 & $5.75 \pm 0.070^{*}$ & 43.39 \\
\hline Winter & $4.40 \pm 0.073$ & $6.48 \pm 0.083^{*}$ & 47.27 & $6.37 \pm 0.077^{*}$ & 44.77 & $6.40 \pm 0.086^{*}$ & 45.45 \\
\hline Spring & $4.44 \pm 0.053$ & $6.37 \pm 0.063^{*}$ & 43.47 & $6.64 \pm 0.060^{*}$ & 49.54 & $7.72 \pm 0.040^{*}$ & 73.87 \\
\hline
\end{tabular}

-Data are presented as mean \pm SE of 6 fish. - SE: standard error. \%Alteration from control value * significant difference from control at $(P \leq 0.05)$.

In T. zilli Fish: The concentrations of total cholesterol in the liver and muscle of $T$. zilli collected from (east, middle and west of Lake Qarun) during four seasons were represented in (Tables 5-6). The present study revealed that total cholesterol in the liver and muscle of T. zilli was increased significantly ( $\mathrm{p} \leq 0.05)$ in comparison with the control fish samples collected from unpolluted site (fish farm) with percentage ranged between 9.20-73.87\% except in the liver sample collected from western part in summer Table 7: Total cholesterol concentrations (mg/dl) (Means \pm SE) in the liver of M. capito collected from Lake Qarun.

\begin{tabular}{|c|c|c|c|c|c|c|c|}
\hline location/season & control & East & \%Alteration & middle & \%Alteration & west & \%Alteration \\
\hline Summer & $2.77 \pm 0.081$ & $5.36 \pm 0.084^{*}$ & 93.5 & $4.09 \pm 0.073^{*}$ & 47.65 & $6.71 \pm 0.050^{*}$ & 142.2 \\
\hline Autumn & $3.13 \pm 0.052$ & $6.29 \pm 0.028^{*}$ & 100.95 & $4.44 \pm 0.049^{*}$ & 41.85 & $5.86 \pm 0.086^{*}$ & 87.22 \\
\hline Winter & $2.89 \pm 0.056$ & $5.94 \pm 0.068^{*}$ & 105.5 & $5.25 \pm 0.065^{*}$ & 81.66 & $6.25 \pm 0.071^{*}$ & 116.2 \\
\hline Spring & $2.85 \pm 0.056$ & $5.86 \pm 0.066^{*}$ & 105.6 & $4.51 \pm 0.072^{*}$ & 58.24 & $6.17 \pm 0.064^{*}$ & 116.4 \\
\hline
\end{tabular}

-Data are presented as mean \pm SE of 6 fish. - SE: standard error. \%Alteration from control value * significant difference from control at (P $\leq 0.05)$.

In M. capito Fish: The concentrations of total cholesterol in the liver and muscle of $M$. capito collected from (east, middle and west of Lake Qarun) during four seasons were represented in (Table 7-8). The present study revealed that total cholesterol in the liver and muscle of T. zilli was increased significantly that was not significant increased with percentage $2.66 \%$. The lowest values in liver and muscle of T. zilli were $(3.28 \pm 0.068$ and $4.44 \pm 0.073 \mathrm{mg} / \mathrm{dl}$ respectively) recorded in autumn in the eastern and middle part of the lake respectively. While, the highest values were $(6.17 \pm 0.090$ and $8.64 \pm 0.056 \mathrm{mg} / \mathrm{dl}$ respectively) recorded during summer in the middle and western part of the lake respectively.

$(p \leq 0.05)$ in comparison with the control fish samples collected from unpolluted site (fish farm) with percentage ranged between $31.03-184.2 \%$. The lowest values in liver and muscle of $M$. capito were $(4.09 \pm 0.073$ and $5.25 \pm 0.070 \mathrm{mg} / \mathrm{dl}$ respectively) recorded in summer and autumn in the middle part respectively. while, 
the highest values were $(6.71 \pm 0.050$ and $11.54 \pm 0.035 \mathrm{mg} / \mathrm{dl})$ in summer and winter in the western part of the lake respectively. In general, total cholesterol concentrations in the liver and muscle Table 8: Total cholesterol concentrations (mg/dl) (Means \pm SE) in the muscle of M. capito collected from Lake Qarun.

\begin{tabular}{|c|c|c|c|c|c|c|c|}
\hline location/season & control & East & \%Alteration & middle & \%Alteration & west & \%Alteration \\
\hline Summer & $4.13 \pm 0.056$ & $9.49 \pm 0.068^{*}$ & 129.7 & $5.67 \pm 0.068^{*}$ & 37.28 & $10.57 \pm 0.078^{*}$ & 155.9 \\
\hline Autumn & $4.01 \pm 0.071$ & $9.88 \pm 0.107^{*}$ & 146.38 & $5.25 \pm 0.070^{*}$ & 30.9 & $9.96 \pm 0.057^{*}$ & 148.3 \\
\hline Winter & $4.06 \pm 0.050$ & $5.32 \pm 0.061^{*}$ & 31.03 & $6.64 \pm 0.095^{*}$ & 63.54 & $11.54 \pm 0.035^{*}$ & 184.2 \\
\hline Spring & $4.24 \pm 0.061$ & $8.64 \pm 0.056^{*}$ & 103.7 & $6.40 \pm 0.040^{*}$ & 50.9 & $9.96 \pm 0.103^{*}$ & 134.9 \\
\hline
\end{tabular}

-Data are presented as mean \pm SE of 6 fish. - SE: standard error. \%Alteration from control value * significant difference from control at (P $\leq 0.05)$.

\section{Discussion}

Aquatic pollution can easily be detected through biomarkers, as biomarkers offer promise as sensitive indicators demonstrating that toxicants have entered organisms that have been distributed between tissues and are eliciting a toxic effect at critical targets. Biomarkers are measurable responses to the exposure of an organism to xenobiotics as well as very good biosensors of aquatic contaminants. Biomarkers are measurements in body fluids, cells or tissues indicating biochemical or cellular modifications due to the presence and magnitude of toxicants, or of host response [14]. Lipid play an important role in metabolic activities of animals because they are source of energy and are involved in the building of cellular components. They are stored in the form of metabolites and provide energy when an organism faces adverse conditions.

In the present study, triglycerides and total cholesterol in fish tissues of (T. zilli and M. capito) collected from different sites of Lake Qarun were markedly sensitive to the environmental pollution of the lake. They were increased significantly $(\mathrm{p} \leq 0.05)$ compared to control value in all seasons and regions. The elevation in the triglycerides, total Cholesterol and total lipid may be attributed to enhanced lipid synthesis and/or reduced lipid catabolism. Also, the observed increase in lipid in fish tissues may be because excess energy reserves (as glucose, triglycerides and cholesterol) are required by organisms to mediate the effects of stress [15].

Another reason for increasing in the triglycerides concentration in the present study may be due to the hypo activity of lipoprotein lipase enzyme which breaks triglycerides. Also, there is several ways by which toxic materials can elevate levels of total cholesterol and total lipid in fish blood or tissues: 1) increase production by liver and other tissues, 2) release of cholesterol and other lipids constituents from damaged cell membranes, 3) decreased hepatic excretion of cholesterol [16]. Our results of the increase in triglycerides, total Cholesterol and total lipid agreed with Muralidhana and sabae and Mohamed [17-18].

\section{Conclusion}

It was concluded that environmental pollutants have harmful effects on the biochemistry of different tissues (liver and muscle). There were changes in the activities of triglycerides and total cholesterol concentrations. The level of Triglycerides and total cholesterol in the liver and muscle of fish T. zillii and M. capito of Lake of T. zilli and $M$. capito fish were increased significantly ( $\mathrm{p} \leq 0.05)$ compared to the control values during four seasons.

Qarun increased significantly $(\mathrm{p} \leq 0.05)$ compared to the control value.

\section{References}

1. Mansour SA and MM Sidky (2003) Ecotoxicological studies. 6. The first comparative study between Lake Qarun and Wadi El-Rayan Wetland (Egypt), with respect to contamination of their major components. Food Chemistry 82: 181-189.

2. David M H, Ramesh V patil, S Marigoudar and Chetti S (2010) Sodium cyanide induced modulations the activities of some oxidative enzyme and metabolites on the fingerlings C. carpio. Toxicalogical and Environment chemistry 92: 1841-1849.

3. Velkova Jordanoska L, Kostoski G, Jordanoska B (2008) Antioxidative enzymes in fish as biochemical indicators of aquatic pollution. Bulg J Agric Sci 14: 235-237.

4. Cole T G, Klotzsch S G, McNamara J R (1997) Measurement of Triglyceride Concentration in Handbook of Lipoprotein Testing. In: N Rifai (Edsn) AACC Press, Washington DC, pp. 115.

5. Rifai N, Bachorik PS, Albers JJ (2001) Lipids, Lipoproteins, and Apolipoproteins in Tietz Fundamentals of Clinical Chemistry. In: C. Burtis, ER Ashwood (Eds) WB Saunders Company, Philadelphia, pp. 462-493.

6. Mir A H (2015) impact of anthropogenic activities on the biochemical parameters of labeo calbasu caught from betwa river in raisen district (m.p). Indian Streams Research Journal (5): 1-5.

7. Gad N S (1999) Bioassay studies for assessment of some pesticide on Tilapia zilli living in fresh and saline water, Shams University Pp 223.

8. Javed M and Usmani N (2014) Stress response of biomolecules (carbohydrate, protein and lipid profiles) in fish hanCna punctatus inhabiting river polluted by Thermal Power Plant effluent. Saudi Journal of Biological Sciences 09 -021.

9. Heath AG (1995) Water pollution and fishphysiology. In: $2^{\text {nd }}(e d n)$, Lewis Publisher, New York, London, pp. 359.

10.Zubay G (1993) Biochemistry. In: $3^{\text {rd }}($ edn). Brown publishers, Texas, USA.

11. Sabae S and Ali M (2004) Distribution of nitrogen cycle bacteria in realation to physiochemical condition of closed saline lake (Lake Qarun Egypt) Journal of Egyptian Academic. Society for Environmental Development 5: 145-167.

12. Wahlefeld AW (1974) Methods of Enzymatic Analysis. In: HU Bergmeyer (Ed). Academic Press, New York, USA, pp.1831-1835.

13. Admundson DM (1999) Journal of Biochemical and Biophysical Methods. 38: 43-52.

14. Sadati F, Shahsavani D, Baghshani H (2013) Biochemical alterations induced by sublethal cyanide exposure in common carp (Cyprinus carpio). J Biol Environ Sci 7(20): 65-69. 
15. Sayed AEH, IAA Mekkawy and UM Mahmoud (2011) Effects of 4-nonylphenol on metabolic enzymes, some ions and biochemical blood parameters of the African catfish Clarias gariepinus (Burchell, 1822). African Journal of Biochemistry Research 5(9): 287-297.

16. Metwally AA (2009) Asurvy of mercury, lead and cadmium in muscles of British free water fish. Chemistry 16(4): 901-906.
17. Muralidhana L (2014) Chronic Toxicity studies on proximate composition of Cypriues carpio exposed to Fenthion. IIOAB Journal 5(3): 1-5.

18. Sabae Z S, Mohamed AS (2015) Effect of Environmental Pollution on the Health of Tilapia spp from Lake Qarun. Global Veterinaria 14(3): 304-328.

Your next submission with Juniper Publishers will reach you the below assets

- Quality Editorial service

- Swift Peer Review

- Reprints availability

- E-prints Service

- Manuscript Podcast for convenient understanding

- Global attainment for your research

- Manuscript accessibility in different formats

( Pdf, E-pub, Full Text, Audio)

- Unceasing customer service

Track the below URL for one-step submission https://juniperpublishers.com/online-submission.php 